\title{
Parasite Community of Cichla kelberi (Perciformes, Cichlidae) in the Três Marias Reservoir, Minas Gerais, Brazil
}

\author{
Comunidade parasitária de Cichla kelberi (Perciformes, Cichlidae) do Reservatório de \\ Três Marias, Minas Gerais, Brasil \\ Michelle Daniele Santos-Clapp ${ }^{1 *}$; Marilia Carvalho Brasil-Sato ${ }^{2}$ \\ ${ }^{1}$ Centro Setorial de Ciências Biológicas e da Saúde - CCBS, Centro Universitário Estadual da Zona Oeste - UEZO, \\ ${ }^{2}$ Departamento de Biologia Animal, Universidade Federal Rural do Rio de Janeiro - UFRRJ, Seropédica, RJ, Brasil
} Rio de Janeiro, RJ, Brasil

Received May 07, 2014

Accepted June 11, 2014

\begin{abstract}
A total of 112 specimens of yellow peacock bass, Cichla kelberi, were collected in the Três Marias Reservoir, upper São Francisco River, State of Minas Gerais, between 2004 and 2005. Twelve species of parasites were collected: two species of ectoparasites (the monogenetic Gussevia sp. and the copepod Ergasilus sp.); and ten species of endoparasites, including four species of adult endoparasites: the cestodes Proteocephalus macrophallus and P. microscopicus, and the nematodes: Capillostrongyloides sentinosa and Rhabdochona acuminata, and six species of larval endoparasites: the metacercariae of Austrodiplostomum compactum and the nematodes: Hysterothylacium sp., Contracaecum sp. Type 1, Procamallanus (Spirocamallanus) inopinatus, Spiroxys sp., and Goezia sp.. A significant positive correlation in the abundance of the two adult endoparasites species, P. macrophallus and P. microscopicus, may indicate that such associated species had the same ecological requirements. The positive correlations between the prevalence of the larval endoparasites, Hysterothylacium sp. and A. compactum, may indicate that there was opportunism for the two generalists species. Ergasilus sp., C. sentinosa, R. acuminata and Hysterothylacium sp. were recorded for the first time in C. kelberi, and this increased their list of known hosts. In addition, both proteocephalid species and C. sentinosa can extend their known biogeographical distribution to the Três Marias Reservoir.
\end{abstract}

Keywords: Helminths, larval anisakid nematodes, fish parasites.

\section{Resumo}

Cento e doze espécimes de Cichla kelberi foram coletados no Reservatório de Três Marias, Alto São Francisco, Três Marias, MG, entre 2004 e 2005. Foram coletadas doze espécies de parasitos matazoários, sendo duas espécies de ectoparasitos: os monogenéticos Gussevia sp. e os copépodos Ergasilus sp.; e dez espécies de endoparasitos, sendo quatro espécies de endoparasitos adultos: os cestoides Proteocephalus macrophallus e P. microscopicus e os nematoides: Capillostrongyloides sentinosa e Rhabdochona acuminata, além de seis espécies de endoparasitos larvais: metacercárias de Austrodiplostomum compactum e os nematoides: Hysterothylacium sp., Contracaecum sp. Tipo 1, Procamallanus (Spirocamallanus) inopinatus, Spiroxys sp. e Goezia sp.. As associaçôes positivas significativas observadas para os endoparasitos adultos $P$. macrophallus e P. microscopicus com correlação positiva entre suas abundâncias podem indicar que essas espécies tenham os mesmos requerimentos ecológicos; e para as espécies de endoparasitos larvais Hysterothylacium sp. e A. compactum, com correlaçóes positivas entre suas prevalências podem indicar que houve oportunismo para ambas as espécies. Ergasilus sp., C. sentinosa, R. acuminata e Hysterothylacium sp. são registrados pela primeira vez em C. kelberi, ampliando assim a listagem de hospedeiros. Portanto, o Reservatório de Três Marias constitui nova localidade para ambas as espécies de proteocefalídeos e para C. sentinosa, ampliando assim a distribuiçáo geográfica.

Palavras-chave: Helmintos, nematóides anisaquídeos larvais, parasitos de peixes.

\footnotetext{
*Corresponding author: Michelle Daniele Santos-Clapp

Centro Setorial de Ciências Biológicas e da Saúde - CCBS, Centro

Universitário Estadual da Zona Oeste - UEZO, Av. Manuel Caldeira de

Alvarenga, 1203, Campo Grande, CEP 23070-200, Rio de Janeiro, RJ, Brasil

e-mail: michelledaniele@yahoo.com.br
} 


\section{Introduction}

Species of the genus Cichla Schneider, 1801, which is also known as the peacock bass, originate from the Amazon Basin and represent the major group of piscivorous fish in the Cichlidae in South America (LOWE-MCCONNEL, 1991).

The introduction of species is a type of ecological change that can modify the biotic community in which the species has been introduced (LI; MOYLE, 1981). The presence of the exotic species Cichla kelberi Kullander \& Ferreira, 2006, in the Três Marias Reservoir, upper São Francisco River, has been confirmed by experimental fishing since 1982, and there are indications that the species may have found favorable reproductive conditions in this reservoir (SATO; GODINHO, 1999).

There are scarce studies on the impacts of the introduction of exotic species into reservoirs in Brazil. According to Sunaga and Verani (1997), there is the possibility that exotic fishes, such as the peacock bass Cichla ocellaris Schneider, 1801 and piranha Pygocentrus nattereri Kner, 1858, have caused damage in the structure of fish communities in the lakes in the middle Doce River. Godinho et al. (1994) reported a lower richness and abundance of species; smaller sized individuals in the little ponds of the middle Doce River were subject to the introduction of $C$. ocellaris and P. nattereri. Moreover, losses in the fish community may have occurred in the Redonda Lagoon, State of Rio Grande do Norte, by the introduction of C. ocellaris (MOLINA et al., 1996). On the other hand, the introduction of peacock bass, Cichla monoculus Agassiz, 1831, and croaker Plagioscion squamosissimus (Heckel, 1840) in the Paraná River basin have had great economic importance in the region (AGOSTINHO; JÚLIO JR, 1999). Impacts on the structure of the native fish community of the Três Marias Reservoir caused by the introduction of $C$. kelberi are still unknown.

Cichla kelberi lives in lentic environments where it reproduces mainly during the rainy season (ZARET, 1980) and shows sexual dimorphism during the breeding season, when a post-occipital protuberance appears in male individuals (FONTENELE, 1948). This species provides parental care to its offspring and has a high fertility rate; there is the presence of adhesive organs in the larvae that prevent them from being carried by the currents (FONTENELE, 1950). The species also builds nests (BRAGA, 1952), and it presents fractional spawning (MAGALHÃES et al., 1996), an aeration capacity of its eggs independent of the rate of oxygen dissolved in water (ZARET, 1980), and piscivorous feeding behavior (GOMES, 2002).

The yellow peacock bass, as it is popularly known, has light spots on its pelvic, anal, and caudal fins - a characteristic that distinguishes it from other species of peacock bass. It is naturally distributed in the Araguaia River basin, in the states of Mato Grosso and Goiás, and the lower Tocantins River, State of Pará. It has been introduced into several reservoirs in the states of Rio Grande do Norte, Minas Gerais, and Ceará, and C. monoculus and C. ocellaris have been introduced into the Paraíba do Sul River, State of Rio de Janeiro, and the Rio Paraná basin, State of Paraná, extending into Paraguay (KULLANDER; FERREIRA, 2006).

Few studies have been conducted on the parasite fauna of C. kelberi to date. Araujo et al. (2009) recorded the nematode,
Procamallanus (Spirocamallanus) inopinatus (Travassos, Artigas \& Pereira, 1928), in C. kelberi from the Ingazeira Weir, Paulistana, State of Piauí. Yamada (2008) recorded the monogeneans Sciadicleithrum ergensi Kritsky, Thatcher, and Boeger, 1989, Sciadicleithrum uncinatum Kritsky, Thatcher, and Boeger, 1989, Gussevia longihaptor (Mizelle \& Kritsky, 1969), Gussevia undulata Kritsky, Thatcher, and Boeger, 1986, and Ascocotyle sp. (metacercariae) in peacock basses collected in the Itaipú Reservoir, State of Paraná. Yamada et al. (2011) inventoried the ectoparasites S. ergensi, Gussevia tucunarense Kritsky, Thatcher, and Boeger, 1986, G. undulata and Ascocotyle sp. of peacock basses collected in the Lajes Reservoir, State of Rio de Janeiro. Ramos et al. (2013) recorded metacercariae of Austrodiplostomum compactum (Lutz, 1928) in C. kelberi from the Chavantes Reservoir, State of São Paulo. In addition, Yamada and Takemoto (2013) collected specimens of C. kelberi in three Brazilian reservoirs: Jupiá, Rosana, and Marechal Dutra. The cestode Proteocephalus microscopicus Woodland, 1935, and the larval nematode Contracaceum sp. were found in peacock basses from the three reservoirs mentioned; the Rosana Reservoir was the only one in which peacock basses were infested by ectoparasites, such as S. ergensi, G. tucunarense, G. undulata, and Ascocotyle sp.; the cestode, Proteocephalus macrophallus Diesing, 1850, was found in peacock basses from the Rosana and Marechal Dutra Reservoirs; the cestode, Sciadocephalus megalodiscus Diesing, 1850, was collected in peacock basses from the Jupiá and Marechal Dutra Reservoirs; the nematode, Procamallanus (Procamallanus) peracuratus Pinto, Fábio Noronha, and Rolas, 1976, was recorded in fish from the Jupiá Reservoir, as were representatives of Goezia intermedia Rasheed, 1965. Later, Raphidascaris (Sprentascaris) manerti Peter and Cassone, 1984, was found in peacock basses belonging only to the Rosana Reservoir.

The goal of the present study was to identify the component species of the parasite community of $C$. kelberi in the Três Marias Reservoir, so as to contribute to the known parasite biodiversity of cichlid fish from the São Francisco River, Brazil.

\section{Materials and Methods}

A total of 112 specimens of $C$. kelberi were collected in the

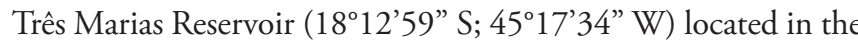
upper Sáo Francisco River, near the Três Marias municipality, State of Minas Gerais, Brazil. The collection was carried out in August 2004, July and August 2005 (dry season); and in January 2004, December 2004, and January 2005 (rainy season). Fish collections were performed with the aid of gillnets that were placed the night before by fishermen of the Estaçáo de Hidrobiologia e Piscicultura of the Companhia de Desenvolvimento dos Vales dos Rios São Francisco e Parnaíba (EPT/CODEVASF).

Specimens of $C$. kelberi were identified according to Kullander and Ferreira (2006). During necropsy of the fish, their total length, weight, and sex were recorded on forms, and the parasite specimens were collected, fixed, and processed for identification in accordance with methodologies used for the study of fish parasites (AMATO et al., 1991).

Voucher specimens of $C$. kelberi were deposited in the Museum of Zoology, University of São Paulo (MZUSP), São Paulo, No. 
95148. Voucher specimens of parasites of $C$. kelberi were deposited in the Coleçáo Helmintologica of the Instituto Oswaldo Cruz (CHIOC), Rio de Janeiro, according to the numbering presented in the Results section. The identification of parasites follows specific scientific literature, and the larval nematodes were classified according to Moravec (1998).

Statistical tests were only applied to the parasite species that showed a parasitic prevalence higher than 10\% (BUSH et al., 1990). The ecological descriptors used were in accordance with Bush et al. (1997). Species dominance in communities, as based on the proportion of infected/infested fish, was tested using Simpson's index (C) (STONE; PENCE, 1978); dominance was considered when values were greater than or equal to 0.25 . The frequency of dominance, the shared frequency of dominance, and the mean relative dominance of each parasite species were calculated according to Rohde et al. (1995). The ratio between the mean parasite variance and abundance (dispersion index [DI]) was calculated for each parasite species in order to determine their distribution pattern. Their significance was tested using the statistical $d$-test $(d>1.96)$ (LUDWIG; REYNOLDS, 1988).

Student's $t$-test was used to check for possible differences between the weights and sizes of hosts in relation to their sex. The chi-square test $\left(\mathrm{X}^{2}\right)$, using the Yates correction, and a $2 \times 2$ contingency table, were used to determine the influence of sex and the period of collection on the prevalence of parasites. Spearman's correlation coefficient by ranks $\left(r_{s}\right)$ was used to evaluate possible correlations between the hosts' total length and intensity, abundance, richness, and parasite diversity. Pearson's correlation coefficient $(r)$ was used to assess the correlation between parasite prevalence (using prior angular transformation of the data) in relation to the hosts' size classes, as estimated by Sturges's formula (STURGES, 1926). The Mann-Whitney $U$-test was used to assess the possible differences between intensity, abundance, richness, and parasite diversity in relation to the sex and period of collection of hosts. The statistical analyses applied to the parasite infrapopulations and parasite community were performed in accordance with the methods of Zar (2006).

The community descriptors of parasitism that were calculated included the following: mean parasite abundance; mean parasite richness; Shannon-Wiener's parasite diversity $(H)$; and Hill's equivalence modified $(E)$. The DivEs software was used to calculate these indexes (RODRIGUES, 2007). Berger-Parker's numerical dominance $(D b p)$, as based on parasite infracommunities, was calculated from the respective abundances (MAGURRAN, 1988). The level of significance for all tests was $p<0.05$.

\section{Results}

A total of 112 specimens of $C$. kelberi were collected, of which 59 were males, with a mean total length of $29.6 \pm 6.2 \mathrm{~cm}$ $(18.0-48.0 \mathrm{~cm})$ and mean weight of $419.2 \pm 285.3 \mathrm{~g}(85.0-1540 \mathrm{~g})$; 53 were females, with a mean total length of $28.4 \pm 4.4 \mathrm{~cm}$ $(20.0-35.5 \mathrm{~cm})$, weighing $366.9 \pm 179.7 \mathrm{~g}(85.0-684.0 \mathrm{~g})$. There was no statistically significant difference in terms of the total length and weight between male and female hosts $(t=1.17$, $p=0.24 ; t=1.15, p=0.25$ ).

\section{Component parasite community}

Not all fish of the sample analyzed were parasitized $(n=9)$. Twelve species of metazoan parasites were collected. Two species were ectoparasites and ten were endoparasites; there were four species of adult endoparasites and six species of larval endoparasites, totaling 3205 specimens and an average of 28.6 parasites per fish.

With respect to Crustacea, the collection included Ergasilus sp., which is representative of copepods. With respect to Monogenea, the collection included Gussevia sp.. Four species were found among adult endoparasites, two Eucestoda: P. macrophallus and P. microscopicus, and two Nematoda: Capillostrongyloides sentinosa (Travassos, 1927) and Rhabdochona acuminata (Molin, 1860). Among the larval endoparasites, six species of parasites were collected, one being Digenea: $A$. compactum (metacercariae), and five being Nematoda: Hysterothylacium sp.; Contracaecum sp. ${ }_{\text {Type }}$ ; P. (S.) inopinatus; Spiroxys sp.; and Goezia sp..

Regarding the parasite community of $C$. kelberi, the metacercariae of $A$. compactum were the most prevalent $(59.8 \%)$, followed by the larvae of Hysterothylacium sp. (58\%) (Table 1).

Simpson's dominance index $(C)$ indicated that there was no dominance in the parasite community of $C$. kelberi $(C=0.21)$, even though $P$. macrophallus and Hysterothylacium sp. presented with higher frequency of dominance values (Table 2).

The metazoan parasites of $C$. kelberi showed the typical pattern of aggregated or superdispersed distribution, which is a common ictioparasitology pattern, as shown in Table 3. The parasite community of $C$. kelberi presented with $H^{\prime}=0.55, E=2.40$, $\mathrm{D}_{\mathrm{bp}}=0.55$, a mean parasite richness of $2.12 \pm 1.13$, and a mean parasite abundance of $28.6 \pm 66.6$.

\section{Parasite infracommunities}

The sample analyzed included 53 females and 59 males of C. kelberi. The females had a mean diversity $0.21 \pm 0.14(0-0.60)$ and a richness of $2.11 \pm 1.28(0-5)$ species. The males showed $0.20 \pm 0.17(0-0.62)$ and $2.10 \pm 0.99(0-5)$, respectively. There was no statistically significant difference between the parasite diversity and parasite richness values with respect to the hosts' sex ( $U=1221.5, p=0.58 ; U=1529.0, p=0.84$, respectively). The parasite indexes of the five parasite species analyzed were not influenced by the sex of $C$. kelberi (Table 4) during the entire collection period. The mean total abundance was not correlated with the sex of the fish $(U=1520.0, p=0.80)$.

The abundance of $P$. macrophallus was higher in fish with smaller total length, representing a negative correlation (Table 5). The diversity and richness of parasite infracommunities were not correlated with the total length of the hosts $\left(r_{s}=-0.15, p=0.12\right.$; $r=-0.015, p=0.88$, respectively). The mean total abundance proved to be negatively correlated with the size of the fish $\left(r_{\mathrm{s}}=-0.19, p=0.04\right)$.

A total of 62 specimens of $C$. kelberi were collected during the dry season and 50 specimens were collected during the rainy season. The mean prevalence, intensity, and abundance of the parasites found are shown in Table 6. The fish collected during the dry season showed a mean parasite diversity of $0.19 \pm 0.15$ (0-0.62) and a mean parasite richness of $2.69 \pm 1.08$ ( $0-5$ species). 
Table 1. Prevalence (P); intensity amplitude (IA); mean intensity (MI); and mean abundance (MA), with the corresponding standard deviation $(\mathrm{SD})$ and sites of infection/infestation $\left(\mathrm{G}=\right.$ gills, $\mathrm{C}=$ coelom, $\mathrm{S}=$ stomach, $\mathrm{A}_{\mathrm{I}=}$ anterior intestine, $\mathrm{M}_{\mathrm{I}=}$ middle intestine, $\mathrm{P}_{\mathrm{I}=}$ posterior intestine, $\mathrm{N}=$ nostrils, $\mathrm{E}=$ eyes) of the metazoan parasites of Cichla kelberi Kullander \& Ferreira, 2006, in the Três Marias Reservoir, upper São Francisco River, State of Minas Gerais, Brazil.

\begin{tabular}{|c|c|c|c|c|c|}
\hline Parasite species & $\mathbf{P}(\%)$ & IA & $\mathrm{MI} \pm \mathrm{SD}$ & $\mathrm{MA} \pm \mathrm{SD}$ & $\begin{array}{l}\text { Site of infection/ } \\
\text { infestation }\end{array}$ \\
\hline $\begin{array}{l}\text { Digenea } \\
\text { Austrodiplostomum compactum (metacercariae) } \\
\text { CHIOC } 36964\end{array}$ & 59.8 & $1-40$ & $4.76 \pm 6.70$ & $2.85 \pm 5.67$ & E \\
\hline $\begin{array}{l}\text { Monogenea } \\
\text { Gussevia sp. } \\
\text { CHIOC } 35554\end{array}$ & 16.1 & $1-11$ & $2.61 \pm 2.59$ & $0.42 \pm 1.40$ & G \\
\hline $\begin{array}{l}\text { Eucestoda } \\
\text { Proteocephalus macrophallus } \\
\text { CHIOC } 36962\end{array}$ & 36.6 & $1-648$ & $42.68 \pm 102.3$ & $15.62 \pm 64.81$ & $C, A_{I}, M_{I}, P_{I}$ \\
\hline $\begin{array}{l}\text { Proteocephalus microscopicus } \\
\text { CHIOC } 36963\end{array}$ & 27.7 & $1-107$ & $16.71 \pm 23.7$ & $4.62 \pm 14.42$ & $S, A_{I}, M_{I}, P_{I}$ \\
\hline $\begin{array}{l}\text { Nematoda } \\
\text { Capillostrongyloides sentinosa } \\
\text { (adult) }\end{array}$ & 0.9 & 1 & 1.0 & $0.009 \pm 0.09$ & S \\
\hline $\begin{array}{l}\text { Rhabdochona acuminata } \\
\text { (adult) }\end{array}$ & 0.9 & 1 & 1.0 & $0.009 \pm 0.09$ & $\mathrm{C}$ \\
\hline $\begin{array}{l}\text { Hysterothylacium sp. (larvae) } \\
\text { CHIOC } 36965\end{array}$ & 58.0 & $1-57$ & $8.51 \pm 12.1$ & $4.94 \pm 10.11$ & $C, S, A_{I}, M_{I}, P_{I}$ \\
\hline $\begin{array}{l}\text { Contracaecum sp. } \\
\text { CHIPe } 1 \text { (larvae) } \\
\text { CHIC } 35555\end{array}$ & 1.8 & 1 & 1.0 & $0.018 \pm 0.13$ & $C, M_{I}$ \\
\hline $\begin{array}{l}\text { Procamallanus (S.) inopinatus (larvae) } \\
\text { CHIOC } 35556\end{array}$ & 1.8 & 1 & 1.0 & $0.018 \pm 0.13$ & $A_{I} \cdot M_{I}$ \\
\hline $\begin{array}{l}\text { Spiroxys sp. (larvae) } \\
\text { CHIOC } 35557\end{array}$ & 1.8 & 1 & 1.0 & $0.018 \pm 0.13$ & $C, M_{I}$ \\
\hline $\begin{array}{l}\text { Goezia sp. (larvae) } \\
\text { CHIOC } 35558\end{array}$ & 1.8 & 1 & 1.0 & $0.018 \pm 0.13$ & $\mathrm{C}, \mathrm{A}_{\mathrm{I}}$ \\
\hline $\begin{array}{l}\text { Copepoda } \\
\text { Ergasilus sp. } \\
\text { CHIOC } 36966 \\
\end{array}$ & 3.6 & $1-4$ & $2.00 \pm 1.41$ & $0.07 \pm 0.44$ & $\mathrm{G}, \mathrm{N}$ \\
\hline
\end{tabular}

Table 2. Frequency of dominance, shared frequency of dominance, and mean relative dominance of the metazoan parasites of Cichla kelberi Kullander \& Ferreira, 2006, Três Marias Reservoir, upper São Francisco River, State of Minas Gerais, Brazil.

\begin{tabular}{lccc}
\hline \multicolumn{1}{c}{ Parasite species } & Frequency of dominance & $\begin{array}{c}\text { Shared frequency of dominance } \\
\text { Mean relative dominance } \\
\pm \text { Standard deviation }\end{array}$ \\
\hline Austrodiplostomum compactum & 23 & 6 & $0.236 \pm 0.332$ \\
Gussevia sp. & 2 & 1 & $0.033 \pm 0.130$ \\
Proteocephalus macrophallus & 31 & 1 & $0.242 \pm 0.357$ \\
Proteocephalus microscopicus & 9 & 1 & $0.109 \pm 0.243$ \\
Hysterothylacium sp. & 30 & 3 & $0.281 \pm 0.369$ \\
\hline
\end{tabular}

The fish collected during the rainy season showed $0.22 \pm 0.16$ (0-0.60) and $1.38 \pm 0.69$ (0-2 species), respectively. The parasite richness was significantly correlated with the period of collection ( $U=482.0, p<0.0001)$, unlike the parasite diversity $(U=1133.0$, $p=0.25)$.

Some of the parasite parameters of Hysterothylacium sp. were significantly higher during the dry season, unlike the prevalence and abundance of $P$. macrophallus, which were significantly higher in the rainy season (Table 7 ).
Parasite infracommunities of $C$. kelberi showed a mean diversity $0.20 \pm 0.16$. The infracommunity with the highest parasite diversity $\left(H^{\prime}=0.62\right)$ presented five species of parasites and $E=3.74$. A total of 22 infracommunities showed minimal diversity $\left(H^{\prime}=0\right)$.

There were two associations in the parasite community of C. kelberi: one among adult endoparasites with a correlation between their abundances; and one association between the prevalence of larval endoparasites (Table 8). 
Table 3. Values of the dispersion index and the statistical $d$-test of the metazoan parasites of Cichla kelberi Kullander \& Ferreira, 2006, Três Marias Reservoir, upper São Francisco River, State of Minas Gerais, Brazil.

\begin{tabular}{lcc}
\hline \multicolumn{1}{c}{ Parasite species } & Dispersion index & $d$ \\
\hline Austrodiplostomum compactum & 11.306 & $35.233^{*}$ \\
Gussevia sp. & 4.664 & $17.314^{*}$ \\
Proteocephalus macrophallus & 268.869 & $229.447^{*}$ \\
Proteocephalus microscopicus & 44.969 & $85.050^{*}$ \\
Hysterothylacium sp. & 20.688 & $52.904^{*}$ \\
\hline
\end{tabular}

*significant values.

Table 4. Analysis of parasite indexes under possible influence of the sex of Cichla kelberi Kullander \& Ferreira, 2006, Três Marias Reservoir, upper São Francisco River, State of Minas Gerais, Brazil.

\begin{tabular}{lcccccc}
\hline \multirow{2}{*}{ Parasite species } & \multicolumn{2}{c}{ Prevalence } & \multicolumn{2}{c}{ Intensity } & \multicolumn{2}{c}{ Abundance } \\
\cline { 2 - 6 } & $\boldsymbol{X}^{\mathbf{2}}$ & $\boldsymbol{p}$ & $\boldsymbol{U}$ & $\boldsymbol{p}$ & $\boldsymbol{U}$ \\
\hline Austrodiplostomum compactum & 2.63 & 0.10 & 505.50 & 0.66 & 1265.50 & 0.08 \\
Gussevia sp. & 0.06 & 0.80 & 30.00 & 0.37 & 1549.50 & 0.93 \\
Proteocephalus macrophallus & 0.001 & 0.97 & 145.00 & 0.09 & 1465.00 & 0.56 \\
Proteocephalus microscopicus & 1.43 & 0.23 & 83.50 & 0.16 & 1468.50 & 0.57 \\
Hysterothylacium sp. & 0.09 & 0.76 & 481.00 & 0.72 & 1465.00 & 0.56 \\
\hline
\end{tabular}

Table 5. Analysis of parasite indexes under possible influence of the total length of Cichla kelberi Kullander \& Ferreira, 2006, Três Marias Reservoir, upper São Francisco River, State of Minas Gerais, Brazil.

\begin{tabular}{lcccccc}
\hline \multicolumn{1}{c}{ Parasite species } & \multicolumn{2}{c}{ Prevalence } & \multicolumn{2}{c}{ Intensity } & \multicolumn{2}{c}{ Abundance } \\
\cline { 2 - 7 } & $\boldsymbol{r}$ & $\boldsymbol{p}$ & $\boldsymbol{r}_{\mathrm{s}}$ & $\boldsymbol{p}$ & $\boldsymbol{r}_{\mathrm{s}}$ & $\boldsymbol{p}$ \\
\hline Austrodiplostomum compactum & 0.37 & 0.40 & -0.06 & 0.59 & -0.07 & 0.45 \\
Gussevia sp. & -0.44 & 0.31 & -0.12 & 0.63 & -0.15 & 0.09 \\
Proteocephalus macrophallus & -0.78 & 0.06 & -0.09 & 0.58 & -0.23 & $0.01^{*}$ \\
Proteocephalus microscopicus & -0.22 & 0.67 & -0.03 & 0.85 & -0.14 & 0.15 \\
Hysterothylacium sp. & -0.72 & 0.06 & 0.19 & 0.12 & 0.06 & 0.52 \\
\hline
\end{tabular}

*significant values.

Table 6. Mean prevalence, intensity, and abundance of the metazoan parasites of Cichla kelberi Kullander \& Ferreira, 2006, in the respective collection period (dry and rainy seasons), Três Marias Reservoir, upper São Francisco River, State of Minas Gerais, Brazil.

\begin{tabular}{|c|c|c|c|c|c|c|}
\hline \multirow{2}{*}{ Parasites species } & \multicolumn{2}{|c|}{ Prevalence (\%) } & \multicolumn{2}{|c|}{ Mean intensity } & \multicolumn{2}{|c|}{ Mean abundance } \\
\hline & Dry & Rainy & Dry & Rainy & Dry & Rainy \\
\hline \multicolumn{7}{|l|}{ Digenea } \\
\hline Austrodiplostomum compactum & 64.5 & 54.0 & 5.9 & 3.0 & 3.8 & 1.6 \\
\hline \multicolumn{7}{|l|}{ Monogenea } \\
\hline Gussevia sp. & 9.7 & 24.0 & 3.0 & 2.4 & 0.3 & 0.6 \\
\hline \multicolumn{7}{|l|}{ Eucestoda } \\
\hline Proteocephalus macrophallus & 24.2 & 52.0 & 28.3 & 51.0 & 6.8 & 26.5 \\
\hline Proteocephalus microscopicus & 29.0 & 26.0 & 9.5 & 26.7 & 2.7 & 6.9 \\
\hline \multicolumn{7}{|l|}{ Nematoda } \\
\hline Capillostrongyloides sentinosa & - & 2.0 & - & 1.0 & - & 0.02 \\
\hline Rhabdochona acuminata & - & 2.0 & - & 1.0 & - & 0.02 \\
\hline Hysterothylacium sp. & 62.9 & 52.0 & 12.3 & 2.8 & 7.7 & 1.5 \\
\hline Contracaecum sp. & 1.6 & 2.0 & 1.0 & 1.0 & 0.02 & 0.02 \\
\hline Procamallanus (S.) inopinatus & - & 4.0 & - & 1.0 & - & 0.04 \\
\hline Spiroxys sp. & 1.6 & 2.0 & 1.0 & 1.0 & 0.02 & 0.02 \\
\hline Goezia sp. & 3.2 & - & 1.0 & - & 0.03 & - \\
\hline \multicolumn{7}{|l|}{ Copepoda } \\
\hline Ergasilus sp. & 3.2 & 4.0 & 1.5 & 2.5 & 0.05 & 0.1 \\
\hline
\end{tabular}


Table 7. Analysis of parasite indexes under the possible influence of the collection period (dry and rainy seasons) of Cichla kelberi Kullander \& Ferreira, 2006, Três Marias Reservoir, upper São Francisco River, State of Minas Gerais, Brazil.

\begin{tabular}{lcccccc}
\hline \multirow{2}{*}{ Parasite species } & \multicolumn{2}{c}{ Prevalence } & \multicolumn{2}{c}{ Intensity } & \multicolumn{1}{c}{ Abundance } \\
\cline { 2 - 6 } & $\boldsymbol{X}^{2}$ & $\boldsymbol{p}$ & $\boldsymbol{U}$ & $\boldsymbol{P}$ & 1253.50 \\
\hline Austrodiplostomum compactum & 2.63 & 0.10 & 406.50 & 0.08 & 0.08 \\
Gussevia sp. & 3.21 & 0.07 & 19.000 & 0.12 & 1345.00 \\
Proteocephalus macrophallus & 8.06 & $0.004^{*}$ & 170.00 & 0.51 & 1144.00 & 0.21 \\
Proteocephalus microscopicus & 0.02 & 0.08 & 74.500 & 0.09 & 1545.50 & 0.98 \\
Hysterothylacium sp. & 3.35 & 0.06 & 253.50 & $0.001^{*}$ & 1116.00 & $0.01^{*}$ \\
\hline
\end{tabular}

*significant values.

Table 8. Analysis of the parasitic descriptors of co-occurring species in Cichla kelberi Kullander \& Ferreira, 2006, Três Marias Reservoir, upper São Francisco River, State of Minas Gerais, Brazil.

\begin{tabular}{|c|c|c|c|c|}
\hline \multirow{2}{*}{ Pairs of species } & \multicolumn{2}{|c|}{ Prevalence } & \multicolumn{2}{|c|}{ Abundance } \\
\hline & $X^{2}$ & $p$ & $r s$ & $p$ \\
\hline \multicolumn{5}{|l|}{ Adult endoparasites } \\
\hline Proteocephalus macrocephallus - Proteocephalus microscopicus & 0.91 & 0.17 & 0.24 & $0.01^{*}$ \\
\hline \multicolumn{5}{|l|}{ Larval endoparasites } \\
\hline Austrodiplostomum compactum - Hysterothylacium sp. & 4.81 & $0.03^{*}$ & 0.18 & 0.05 \\
\hline
\end{tabular}

*significant values.

\section{Discussion}

Even though endoparasites predominated over the ectoparasites with respect to the number of species found, there was no dominance of any parasite species in the parasite community of $C$. kelberi.

Austrodiplostomum compacutm showed the highest prevalence value in the parasite community of $C$. kelberi, followed by Hysterothylacium sp.. The proteocephalid cestodes had intermediate prevalence values, and ectoparasites - which were represented by only two species - had low parasitic indexes; this was also the case for the other nematode larvae.

Despite the piscivorous feeding behavior of peacock basses, Gomes and Verani (2003) pointed out that they vary their feeding behavior from microcrustaceans and rotifers to insects and shrimps, and they also feed on fish as they move between habitats. This may explain why there is a low prevalence of adult and larval nematode species, with the exception of the Hysterothylacium sp., whose presence appeared to be accidental. These species should have low transmission rates and less potential to colonize C. kelberi, which may have occurred due to the lower availability of the intermediate hosts in the case of endoparasites, or it may be due to the higher pathogenicity of these parasites, which would cause a more efficient immune response in the hosts (GUIDELLI et al., 2003). It is likely that these nematode larvae use various species of fish to ensure successful parasite transmission.

According to Szidat and Nani (1951), cercariae of diplostomids penetrate actively into the skin of the fish, and they subsequently develop into metacercariae. When fish-eating birds (cormorants and gulls) prey on infected fish, they can acquire these metacercariae which, in this case, will develop into adult worms in the intestine. When the eyes of the hosts have a high number of metacercariae, the fish are immediately known by the fishermen because they present a "verminous cataract" due to the opacity in the lens of the eyes. In the present study, specimens of $A$. compactum, which are representative of the Diplostomidae found free (not encysted) in the eyes (lens and vitreous humor) of peacock bass, include these fish in this listing of intermediate hosts.

Larvae of Hysterothylacium sp. found in the coelomic cavity, stomach, and anterior, middle, and posterior intestines showed high prevalence, with more than $50 \%$ of the fish collected parasitized. It is probable that when specimens of $C$. kelberi feed on smaller prey (fish), they acquire these larvae that accumulate in these fish until they find their definitive hosts. In this case, C. kelberi can also be a paratenic host. According to Bell and Burt (1991), piscivorous fish host more species of endoparasites than non-piscivorous fish; this occurs because of the fact that when piscivorous fish feed on forage fish (smaller), they acquire possible helminth larvae that are present in the food.

In the present day, $P$. macrophallus and $P$. microscopicus are unique endohelminths of Cichla spp., having never been found in other fish species in Brazil (REGO, 1994; MACHADO et al., 2000; THATCHER, 2006; AZEVEDO et al., 2010; KOHN et al., 2011; FRANCESCHINI et al., 2013; LACERDA et al., 2013a; YAMADA; TAKEMOTO, 2013). According Guégan and Kennedy (1993), the fauna of the parasites of a species of fish is influenced from the time it is introduced into a new habitat. Fish introduced to a new location can usually carry a few species of parasites that parasitized them at their location of origin. Subsequently, these fish acquire new parasite species in their new habitat (POULIN; MORAND, 2004). Since C. kelberi is an exotic species, it is possible that the proteocephalid cestodes that were found had been introduced in conjunction with their hosts, because no other species of fish from the Três Marias Reservoir in the upper Sáo Francisco River region, whose parasitic fauna was investigated, presented with such helminths (BRASIL-SATO, 2003; BRASILSATO; SANTOS, 2003, 2005; SANTOS; BRASIL-SATO, 2006; SANTOS, 2008; MONTEIRO et al., 2009). Lacerda et al. (2013b) accepted this hypothesis when they verified that both species 
of proteocephalids present in C. piquiti Kullander \& Ferreira, 2006, from the original environment (Lajeado Reservoir and São Salvador, Tocantins River) continued to parasitize those hosts that were introduced in new places (Jupiá and Itaipu Reservoirs, Paraná River).

All of the parasite species that were analyzed showed a typical pattern of aggregated or superdispersed distribution, which are common patterns in studies on parasites of freshwater fish (MACHADO et al., 2000; GUIDELLI et al., 2003; SANTOS; BRASIL-SATO, 2006).

Significant positive associations were observed in pairs of species of adult endoparasites (P. macrophallus and P. microscopicus), with a positive correlation noted between their abundances; this may indicate that such associated species have the same ecological requirements and that there are probably frequent and common intermediate hosts for the associated species (GUIDELLI et al., 2003). The relationship observed between both generalist species of the larval endoparasites, Hysterothylacium sp. (passive transmission) and $A$. compactum (active transmission), exhibited positive correlations between their prevalence rates; this may indicate that opportunism occurred between the two species, especially since their transmission routes are quite distinct from one another.

Santos et al. (2009) reported the presence of Spiroxys sp. in C. kelberi of Três Marias Reservoir and considered such occurrence as accidental due to the low prevalence rate recorded. The authors also reported the occurrence of these larvae in Pygocentrus piraya (Cuvier, 1819) and Serrasalmus brandtii Lütken, 1875, which are characiforms fish from the Três Marias Reservoir.

Ergasilus sp., C. sentinosa, R. acuminata, and Hysterothylacium sp. have been recorded for the first time in $C$. kelberi, thus expanding the list of hosts. In addition, for both species of proteocephalids and C. sentinosa, the Três Marias Reservoir, in the upper São Francisco River, has now become a new location for these parasite species, thus expanding upon their known geographical distribution.

\section{Acknowledgements}

The authors are grateful to Dr. Yoshimi Sato (EPT/CODEVASF) for the resources provided for this study; to CEMIG/CODEVASF for the work arrangement; and to the UFRRJ/IBAMA (MG), who established a technical-scientific co-operative agreement to provide logistical and material support. Michelle D. Santos-Clapp was supported by a student fellowship from Conselho Nacional de Pesquisa e Desenvolvimento Tecnológico (CNPq-Brazil).

\section{References}

Agostinho AA, Júlio Jr HF. Peixes da bacia do alto Rio Paraná. In: LoweMcConnell RH. Estudos ecológicos de comunidades de peixes tropicais. São Paulo: EDUSP; 1999. p. 374-400

Amato JFR, Boeger WA, Amato SB. Protocolos para laboratório: coleta e processamento de parasitos de pescado. Seropédica: Imprensa Universitária, Universidade Federal Rural do Rio de Janeiro; 1991. 81 p.

Araujo CSO, Barros MC, Gomes ALS, Varella AMB, Viana GM, Silva NP, et al. Parasitas de populaçóes naturais e artificiais de tucunaré (Cichla spp.). Rev Bras Parasitol Vet 2009; 18(1): 34-38. PMid:19500458. http:// dx.doi.org/10.4322/rbpv.01801006

Azevedo RK, Abdallah VD, Luque JL. Acanthocephala, Annelida, Arthropoda, Myxozoa, Nematoda and Platyhelminthes parasites of fishes from the Guandu river, Rio de Janeiro, Brazil. CheckList 2010; 6(4): 659-667.

Bell G, Burt A. The comparative biology of parasite species diversity: internal helmints of freshwater fish. J Anim Ecol 1991; 60(3): 1047-1063. http://dx.doi.org/10.2307/5430

Braga RA. Ninhos de tucunarés, Cichla temensis Humboldt e Cichla ocellaris Bloch \& Schneider. Rev Bras Zool 1952; 12(3): 273-278.

Brasil-Sato MC. Parasitos de Peixes da Bacia do São Francisco. In: Godinho HP, Godinho AL. Águas, Peixes e Pescadores do São Francisco das Minas Gerais. Belo Horizonte: Pucminas; 2003. p. 149-165.

Brasil-Sato MC, Santos MD. Helmintos de Myleus micans (Lütken, 1875) (Characiformes: Serrasalminae) do Rio São Francisco, Brasil. Rev Bras Parasitol Vet 2003; 12(3): 131-134.

Brasil-Sato MC, Santos MD. Metazoan parasites of Conorhynchos conirostris (Valenciennes, 1840), endemic siluriform fish of the São Francisco Basin, Brazil. Rev Bras Parasitol Vet 2005; 14(4): 160-166.

Bush AO, Aho JM, Kennedy CR. Ecological versus phylogenetic determinants of helminth parasite community richness. Evol Ecol 1990; 4(1): 1-20. http://dx.doi.org/10.1007/BF02270711

Bush AO, Lafferty KD, Lotz JM, Shostak, AW. Parasitology meets ecology on its own terms: Margolis et al. revisited. J Parasitol 1997; 83(4): 575583. PMid:9267395. http://dx.doi.org/10.2307/3284227

Fontenele $\mathrm{O}$. Um caráter sexual secundário extragenital nos Tucunarés (Actinopterygii, Cichlidae). Rev Bras Biol 1948; 8(2): 185-188. PMid:18891726.

Fontenele O. Contribuiçấo para o conhecimento da biologia dos tucunarés (Actinopterygii, Cichlidae) em cativeiro. Aparelho reprodutor. Hábitos de desova e incubaçáo. Rev Bras Biol 1950; 10(4): 503-519.

Franceschini L, Zago AL, Zocoller-Seno MC, Veríssimo-Silveira R, Ninhaus-Silveira A, Silva RJ. Endohelminths in Cichla piquiti (Perciformes, Cichlidae) from the Paraná River, São Paulo State, Brazil. Rev Bras Parasitol Vet 2013; 22(4): 475-484. PMid:24473871. http:// dx.doi.org/10.1590/S1984-29612013000400006

Guégan J, Kennedy CR. Maximum local helminth parasite community richness in Bristish freshwater fish? A test of the colonization time hypothesis. Parasitology 1993; 106(1): 91-100. http://dx.doi. org/10.1017/S0031182000074862

Godinho AL, Fonseca MT, Araújo LM. The ecology of predator fish introductions: the case of Rio Doce valley lakes. In: Pinto-Coelho R, Giani A, Sperling E. Ecology and human impacts on lakes and reservoirs in Minas Gerais with special reference to future development and management strategies. Belo Horizonte: Segrac; 1994. p. 77-83.

Gomes JHC. Ecologia trófica de espécies de peixes do reservatório de Três Marias (MG) [Tese]. São Paulo: Universidade Federal de São Carlos; 2002.

Gomes JHC, Verani JR. Alimentação de espécies de peixes do reservatório de Três Marias. In: Godinho HP, Godinho AL. Águas, peixes e pescadores do São Francisco das Minas Gerais. Belo Horizonte: PucMinas; 2003. p. 195-227. PMid:14556961. 
Guidelli GM, Isaac A, Takemoto RM, Pavanelli GC. Endoparasite infracommunities of Hemisorubim platyrhynchos (Valenciennes, 1840) (Pisces: Pimelodidae) of the Baía River, Upper Paraná floodplain, Brazil: specific composition and ecological aspects. Braz J Biol 2003; 63(2): 261-268. PMid:14509848. http://dx.doi.org/10.1590/S151969842003000200011

Kohn A, Moravec F, Cohen SC, Canzi C, Takemoto RM, Fernandes BMM. Helminths of freshwater fishes in the reservoir of the Hydroelectric Power Station of Itaipu, Paraná, Brazil. CheckList 2011; 7(5): 681-690.

Kullander SO, Ferreira EJG. A review of the South American cichlid genus Cichla, with descriptions of nine species (Teleostei: Cichlidae). Ichthyol Explor Freshwaters 2006; 17(4): 289-398.

Lacerda ACF, Takemoto RM, Poulin R, Pavanelli GC. Parasites of the fish Cichla piquiti (Cichlidae) in native and invaded Brazilian basins: release not from the enemy, but from its effects. Parasitol Res 2013a; 112(1): 279288. PMid:23052767. http://dx.doi.org/10.1007/s00436-012-3135-z

Lacerda ACF, Yamada FH, Antonucci AM, Dias MT. Peixes introduzidos e seus parasitos. In: Pavanelli GC, Takemoto RM, Eiras JC. Parasitologia de peixes de água doce do Brasil. Maringá: Eduem; 2013b. p. 169-193.

Li HW, Moyle PB. Ecological analysis of species introductions into aquatic systems. Trans Am Fish Soc 1981; 110(6): 772-782. http://dx.doi. org/10.1577/1548-8659(1981)110<772:EAOSII>2.0.CO;2

Lowe-McConnell RH. Ecology of cichlids in South American and African waters, excluding the African Great Lakes. In: Keenleyside MHA. (Ed.). Cichlid fishes: behaviour, ecology and evolution. London: Chapman \& Hall; 1991. p. 60-85

Ludwig JA, Reynolds JF. Statistical Ecology: a primer on methods and computing. New York: Wiley-Interscience Publications; 1988. 377 p.

Machado PM, Almeida SC, Pavanelli GC, Takemoto RM. Ecological aspects of endohelminths parasitizing Cichla monoculus Spix, 1831 (Perciformes: Cichlidae) in the Paraná river near Porto Rico, State of Paraná, Brazil. Comp Parasitol 2000; 67(2): 210-217.

Magalhães ALB, Sato Y, Rizzo E, Ferreira RMA, Bazzolli N. Ciclo reprodutivo do tucunaré Cichla ocellaris (Schneider, 1801) na represa de Três Marias, MG. Arq Bras Med Vet Zootec 1996; 48(S1): 85-92.

Magurran AE. Ecological Diversity and Its Measurement. New Jersey: Princeton University Press; 1988. 179 p. http://dx.doi.org/10.1007/97894-015-7358-0

Molina WF, Gurgel HCB, Vieira LJS, Canan B. Ação de um predador exógeno sobre um ecossistema aquático equilibrado. I. Extinçôes locais e medidas de conservação genética. Rev Unimar 1996; 18(2): 335-345.

Moravec F. Nematodes of freshwater fishes of the Neotropical Region. Praha: Academy of Sciences of the Czech Republic; 1998. 464 p.

Monteiro CM, Santos MD, Zuchi NA, Brasil-Sato MC. Ecological parameters of the endohelminths in relation to size and sex of Prochilodus argenteus (Actinopterygii: Prochilodontidae) from the upper São Francisco River, Minas Gerais, Brasil. Zoologia 2009; 26(4): 753-757. http://dx.doi.org/10.1590/S1984-46702009000400021

Poulin R, Morand S. Parasite Biodiversity. Washington: Smithsonian Books; 2004, 215 p.

Ramos IP, Franceschini L, Zago AC, Zica EOP, Wunderlich AC, Carvalho ED, et al. New host records and a checklist of fishes infected with Austrodiplostomum compactum (Digenea: Diplostomidae) in Brazil.
Rev Bras Parasitol Vet 2013; 22(4): 511-518. PMid:24473875. http:// dx.doi.org/10.1590/S1984-29612013000400010

Rego AA. Order Proteocephalidea Mola, 1928. In: Khalil LF, Jones A, Bray RA. (Eds.). Keys to the Cestode Parasites of Vertebrates. New York: CAB Internacional; 1994. p. 257- 293.

Rodrigues WC. DivEs: diversidade de espécies. Versão 2.0. Software e guia do usuário [online] 2007 [cited 2007 Ago 16]. Available from: http:/www.dives.ebras.bio.br/dives2_guia_user.pdf.

Rohde K, Hayward C, Heap M. Aspects of the ecology of metazoan ectoparasites of marine fishes. Int J Parasitol 1995; 25 (8): 945-970. http:// dx.doi.org/10.1016/0020-7519(95)00015-T

Santos MD. Comunidades parasitárias de três espécies de peixes carnivoros do Reservatório de Três Marias, Alto Rio São Francisco, Minas Gerais, Brasil [Tese]. Rio de Janeiro: Universidade Federal Rural do Rio de Janeiro; 2008.

Santos MD, Brasil-Sato MC. Parasitic community of Franciscodoras marmoratus (Reinhardt, 1874) (Pisces: Siluriformes, Doradidae) from the upper São Francisco River, Brazil. Braz J Biol 2006; 66(3): 931-938. PMid:17119841. http://dx.doi.org/10.1590/S151969842006000500019

Santos MD, Albuquerque MC, Monteiro CM, Martins AN, Ederli NB, Brasil-Sato MC. First report of larval Spiroxys sp. (Nematoda, Gnathostomidae) in three species of carnivorous fish from Três Marias Reservoir, São Francisco River, Brazil. Panamjas 2009; 4(3): 306-311.

Sato Y, Godinho H P. Peixes da bacia do rio São Francisco. In: LoweMcConnel RH. Estudos ecológicos de comunidades de peixes tropicais. Sáo Paulo: Edusp; 1999. p. 401-413.

Stone JE, Pence DB. Ecology of helminth parasitism in the bobcat from west Texas. J Parasitol 1978; 64(2): 295-302. http://dx.doi org/10.2307/3279676

Sturges HA. The choice of a class interval. J Am Stat Assoc 1926; 21(153): 65-66. http://dx.doi.org/10.1080/01621459.1926.10502161

Sunaga T, Verani J R. The fish communities of four lakes. In: Tundisi JG, Saijo Y(Eds.). Limnological studies on the Rio Doce Valley Lakes, Brazil. São Paulo: Brazilian Academy of Sciences; 1997. p. 359-369

Szidat L, Nani A. Diplostomiasis cerebralis del pejerrey. Rev Inst Nacional de Investigacion de las Ciencias Naturales 1951; 1(8): 323-384.

Thatcher VE. Amazon fish Parasites. Bulgaria: Pensoft Publ. Sofia; 2006.

Yamada FH. Estudo comparativo e ecológico de ectoparasitos branquiais de Cichla kelberi Kullander \& Ferreira, 2006 (Perciformes, Cichlidae) dos reservatórios de Itaipu-PR e Lajes-RJ, Brasil [Dissertação]. Maringá: Universidade Estadual de Maringá; 2008.

Yamada FH, Takemoto RM. Metazoan parasite fauna of two peacock-bass cichlid fish in Brazil. Check List 2013; 9(6): 1371-1377.

Yamada FH, Santos LN, Takemoto RM. Gill ectoparasite assemblages of two non-native Cichla populations (Perciformes, Cichlidae) in Brazilian reservoirs. J Helminthol 2011; 85(2): 185-191. PMid:20716395. http:// dx.doi.org/10.1017/S0022149X10000441

Zar JH. Biostatistical analysis. 3rd ed. New Jersey: Prentice-Hall: Upper Saddle River; 2006

Zaret TM. Life history and growth relationships of Cichla ocellaris, a predatory South American Cichlid. Biotropica 1980; 12(2): 144-157. http://dx.doi.org/10.2307/2387730 